\title{
PENGARUH PENGUNGKAPAN RELATIONAL CAPITAL PADA KINERJA KEUANGAN PERUSAHAAN (STUDI EMPIRIS PADA PERUSAHAAN HIGH-IC INTENSIVE INDUSTRIES YANG TERDAFTAR DI BURSA EFEK INDONESIA)
}

\author{
Sylvia Christina Daat \\ Fakultas Ekonomi dan Bisnis \\ Universitas Cenderawasih \\ sylviadaat@gmail.com
}

\begin{abstract}
Abstrak: Pengaruh Pengungkapan Relational Capital pada Kinerja Keuangan Perusahaan (Studi Empiris pada perusahaan High-IC Intensive Industries yang Terdaftar di Bursa Efek Indonesia) Penelitian ini dimotivasi oleh berkembangnya arah penelitian akuntansi pada isu-isu terkait aset tidak berwujud (intangible capital), secara khusus intellectual capital (modal intelektual) yang dipicu oleh revolusi dalam teknologi informasi, pentingnya pengetahuan dan bisnis berbasis pengetahuan (knowledge-based business), serta timbulnya inovasi sebagai pola penentu utama keunggulan kompetitif perusahaan. Informasi modal intelektual merupakan salah satu informasi yang dibutuhkan oleh investor karena informasi tentang modal intelektual dapat membantu investor untuk memprediksi kinerja perusahaan di masa yang akan datang, Secara khusus, relational capital sebagai komponen modal intelektual dipandang sebagai salah satu pemicu yang dapat meningkatkan keunggulan kompetitif perusahaan melalui relasi yang kuat dengan stakeholder, dan selanjutnya mampu meningkatkan kinerja perusahaan. Oleh sebab itu, penelitian ini mencoba menemukan bukti empiris pengaruh pengungkapan relational capital pada kinerja keuangan perusahaan High-IC Intensive Industries yang terdaftar di Bursa Efek Indonesia, periode pengamatan 2014 sampai dengan 2017. Sampel penelitian diseleksi dengan metoda purposive sampling dan berdasarkan kriteria yang diterapkan diperoleh total sebanyak 72 observasi perusahaan tahun (firm-year observations) High-IC Intensive Industries yang terdaftar di Bursa Efek Indonesia. Hasil penelitian dengan menggunakan pengujian regresi berganda dengan SPSS ini memberikan bukti empiris bahwa pengungkapan relational capital berpengaruh pada tiga ukuran kinerja keuangan, yaitu: pendapatan bersih, nilai perusahaan, dan arus kas operasi perusahaan.
\end{abstract}

Kata kunci: relational capital, intangible capital, pendapatan bersih, nilai perusahaan, arus kas operasi.

\begin{abstract}
Abstrak: The Impact of Relational Capital on Companies' Financial Performance (Empirical Study on High-IC Intensive Industries Listed on Indonesia Stock Exchange. The development of accounting issues related to intangible capital, especially intellectual capital, urged by information technology capital, the importance of knowledge based business and the emergence of innovation as one of the company's competitive advantage has urged the needs for research related to relational capital. Information on intellectual capital can provide information related to company's future performance for the investors. Specifically, relational capital as the component of intellectual capital is considered as one of the booster of company's competitive advantage due to its strong bound with stakeholder and its ability to improve company's performance. This research aims to provide empirical evidence of the effect of relational capital disclosure on the financial performance of High-IC Intensive Industries listed on Indonesia Stock Exchange in the observation period of 2014 to 2017. The sample is 72 firm year observations of High-IC Intensive Industries listed on Indonesia Stock Exchange in the observation selected based on the determined criteria. The research results showed that relational capital disclosure has effect on three financial performance namely: net income, company's value and company's operational cash flow.
\end{abstract}

Kata kunci: relational capital, intangible capital, net income, company's value, operation cash flow. 


\section{PENDAHULUAN}

\section{Latar Belakang Masalah}

Saat ini modal intelektual (intellectual capital) menarik perhatian banyak akademisi dan komunitas bisnis, karena dipandang memiliki peran yang sangat penting dalam menciptakan dan mempertahankan keunggulan kompetitif serta nilai bagi perusahaan. Seiring berjalannya konfigurasi jaringan ekonomi global, telah terjadi pergeseran paradigma dalam dimensi kehidupan manusia yaitu, dari paradigma lama yang menitikberatkan kekayaan fisik (physical asset) menjadi paradigma baru yang memfokuskan pada nilai aset intelektual (intellectual asset). Modal intelektual merupakan salah satu sumber daya non fisik atau aset tidak berwujud yang tidak terlihat dalam laporan posisi keuangan perusahaan, tetapi semakin diakui sebagai aset strategis dan dipandang penting bagi perusahaan dalam meningkatkan nilai dan keunggulan bersaing berkelanjutan.

Modal Intelektual menjadi perhatian dalam berbagai bidang seperti manajemen, teknologi informasi, sosiologi, dan akuntansi (Guthrie dan Petty, 2000, Sullivan dan Sullivan, 2000). Guthrie dan Petty (2000) berpendapat bahwa pentingnya modal intelektual (IC) disebabkan oleh 4(empat) faktor, yaitu revolusi dalam teknologi informasi, pentingnya pengetahuan dan bisnis berbasis pengetahuan (knowledgebased business), pola aktivitas, serta timbulnya inovasi sebagai pola penentu utama keunggulan kompetitif.

Sejak awal tahun 1990, penelitian terkait modal intelektual telah menggunakan banyak definisi dan istilah-istilah untuk menjelaskan modal intelektual atau aset tak berujud (intangible asset). Dalam berbagai penelitian dari berbagai disiplin ilmu, para peneliti mengidentifikasi modal intelektual atau aset tidak berwujud, sebagai semua sumber daya, properties dan attributes, atau sebagai aset non moneter yang dapat menghasilkan nilai atau manfaat masa depan (Choong, 2008). Modal intelektual didefinisikan sebagai penjumlahan dari komponen-komponen yang dapat memberikan nilai tambah bagi perusahaan. Modal Intelektual adalah kepemilikan pengetahuan dan pengalaman, pengetahuan profesional dan skill, hubungan-hubungan yang baik, dan kapasitas teknologi, yang mana ketika diterapkan akan memberikan keunggulan kompetitif organisasi (CIMA, 2004). Modal intelektual bukan hanya menyangkut pengetahuan dan ketrampilan dari karyawan, melainkan juga termasuk infrastruktur perusahaan, relasi dengan pelanggan, sistem informasi, teknologi, serta kemampuan berinovasi dan bereaksi.

Informasi modal intelektual merupakan salah satu informasi yang 


\section{JURNAL NOMINAL / VOLUME VIII NOMOR 2 / TAHUN 2019}

dibutuhkan oleh investor karena informasi tentang modal intelektual dapat membantu investor untuk memprediksi kinerja perusahaan di masa yang akan datang (Bukh, 2003). Beberapa penelitian telah memberikan bukti empiris pengaruh pengungkapan modal intelektual pada kinerja perusahaan. Penelitian oleh Chen et.al (2005) pada perusahaan publik yang terdaftar di Taiwan Stock Exchange memberikan bukti empiris pengaruh pengungkapan modal intelektual pada kinerja perusahaan saat ini maupun masa yang akan datang. Perusahaan yang memiliki kinerja intelektual yang baik cenderung untuk mengungkapkan modal intelektual yang dimiliki perusahaan dengan lebih baik, karena pengungkapan modal intelektual dapat meningkatkan kepercayaan para stakeholder pada perusahaan.

Dari beberapa perspektif non akuntansi, beberapa definisi telah mengklasifikasikan modal intelektual menjadi 3 komponen yaitu: structural capital, organizational capital, dan relational atau external capital (Sveiby, 1997; Stewart, 1997; Bontis, 2002 dalam Martini et. Al., 2016). Tiga komponen tersebut masing-masing mempunyai peran dalam menciptakan modal intelektual perusahaan yang akhirnya akan menentukan nilai perusahaan. Berbeda dengan human capital dan organisational capital, relational capital menekankan pada nilai yang melekat pada hubungan sebuah perusahaan dengan konsumennya, pemasok, dan konstituen penting lainnya untuk mempertahankan kinerja perusahaan. Relational capital didefinisikan sebagai aset tak berwujud yang didasarkan pada membangun, pengembangan, dan pemeliharaan hubungan yang berkualitas tinggi dengan setiap organisasi, individu, atau kelompokkelompok yang memengaruhi atau berdampak pada perusahaan, termasuk didalamnya: konsumen, pemasok, karyawan, pemerintah, partner, pesaing, dan stakeholder lainnya (Adecco, 2007).

Hasil penelitian Adeeco (2007) menunjukkan bahwa dalam ekonomi berbasis pengetahuan saat ini, mudah bagi pesaing suatu perusahaan untuk membeli teknologi yang sama, mengembangkan produk yang serupa, memperoleh tambahan pendanaan, dan lain sebagainya. Sebagai akibatnya, kinerja perusahaan saat ini semakin ditentukan oleh sumber-sumber modal yang sulit untuk ditiru dan dicontoh oleh pesaing, seperti misalnya modal relasi. Kijek dan Kijek (2007) mengidentifikasi bahwa modal relasi dapat meningkatkan kinerja keuangan perusahaan melalui cost reduction dan peningkatan pangsa pasar. Tidak diragukan lagi bahwa konsumen menjadi komponen terbesar dari stakeholder suatu perusahaan, yang dipandang oleh manager sebagai penentu utama perolehan pendapatan perusahaan. Kepuasan/loyalitas 


\section{JURNAL NOMINAL / VOLUME VIII NOMOR 2 / TAHUN 2019}

konsumen dipandang sebagai faktor kunci untuk menjaga dan mengembangkan pangsa pasar.

Hubungan yang terjalin antara perusahaan dengan para mitranya seringkali disampaikan dalam laporan tahunan. Hal tersebut dilakukan sebagai bentuk penyampaian informasi kepada pengguna laporan bahwa kelangsungan hidup perusahaan didukung oleh berbagai pihak sehingga menciptakan hubungan yang saling menguntungkan dan pada akhirnya berdampak pada peningkatan kinerja perusahaan diantaranya melalui penurunan biaya dan peningkatan pangsa pasar. Oleh sebab itu, pengungkapan relational capital secara positif memengaruhi variabel-variabel yang terkait dengan kinerja keuangan perusahaan dan dapat memicu penciptaan nilai dalam perusahaan (Ashton,2005). Terdapat peningkatan dalam hal ketertarikan peneliti menguji kontribusi pengungkapan modal intelektual, secara khusus relational capital, terhadap peningkatan kinerja perusahaan (Luo et.al., 2004; Chen at.al., 2005; Tan et.al., 2007; Salehi et.al., 2014).

Penelitian oleh Martini et.al. (2016) menguji pengaruh pengungkapan relational capital terhadap beberapa ukuran kinerja keuangan perusahaan pada 80 perusahaan yang listing di Eropa. Hasilnya memberikan bukti empiris pengaruh pengungkapan relational capital terhadap pendapatan, arus kas operasi, dan pengeluaran modal. Namun hasil penelitian tersebut tidak memberikan bukti empiris pengaruh pengungkapan relational capital pada nilai perusahaan. Berdasarkan teori-teori dan hasil-hasil penelitian sebelumnya, maka penelitian ini mempunyai tujuan untuk memperoleh bukti empiris pengaruh pengungkapan relational capital terhadap pendapatan perusahaan, nilai perusahaan dan arus kas operasi bersih perusahaan.

\section{KAJIAN LITERATUR}

Berbagai perspektif teori telah digunakan untuk menjelaskan praktik pengungkapan modal intelektual perusahaan.

\section{Signaling Theory}

Signaling theory menyatakan bahwa perusahaan dengan kinerja yang tinggi menggunakan informasi keuangan untuk mengirim sinyal kepada pasar (Spence, 1973). Perusahaan akan selalu berusaha memberikan sinyal berupa informasi positif kepada para stakeholder, melalui mekanisme pengungkapan (Oliveira, 2006 dalam Cahya, 2013). Pengungkapan informasi yang lengkap akan meningkatkan nilai perusahaan dan manajemen juga akan mendapatkan sorotan atas kinerjanya. Oleh karena itu, manajemen akan mengungkapkan informasi secara menyeluruh meskipun tidak diwajibkan atau bersifat sukarela.

Ketika perusahaan memberikan sinyal positif yaitu berupa informasi yang baik maka pasar juga akan memberikan 
respon yang positif sehingga nilai perusahaan menjadi baik di mata pasar. Signaling theory menunjukkan pentingnya informasi perusahaan bagi keputusan investasi pihak luar. Pengungkapan informasi perusahaan yang menyeluruh, mampu menjelaskan kinerja perusahaan, baik pada masa lau maupun masa yang akan datang. Pada teori ini, perusahaan akan menggunakan mekanisme pengungkapan informasi untuk memberikan sinyal kepada pasar guna mengevaluasi nilai perusahaan.

\section{Teori Stakeholder}

Teori Stakeholder beranggapan bahwa perusahaan yang berkomitmen untuk melaporkan aktivitasnya, termasuk pengungkapan modal intelektual kepada stakeholder biasanya bertujuan untuk mempertahankan keseimbangan dan keberlanjutan pembentukan nilai untuk semua stakeholder (Ernst and Young, 1999).

\section{Modal Intelektual}

Istilah modal intelektual (intellectual capital) pertama kali dikemukan oleh Galbraith pada tahun 1969, yang menulis surat kepada temanya Michael Kalecki. Galbraith menulis: "I wonder if you realize how much those of us the world around have owed to the intellectual capital you have provide over the last decades" (Hudson, 1993 dalam Bontis, 2000). Terdapat berbagai definisi modal intelektual dari beberapa ahli. Menurut Chartered Institute og Management
Accountant (CIMA) dalam Bhasin (2008) modal intelektual merupakan pengetahuan dan pengalaman, kemampuan profesional, hubungan dan kerja sama yang baik, serta kapasitas kemampuan teknologi. Bukh et.al. (2005) mendefinisikan modal intelektual sebagai sumber pengetahuan yang berbentuk karyawan, pelanggan, proses, atau teknologi, yang dapat digunakan perusahaan untuk proses penciptaan nilai. Menurut Heng seperti dikutip oleh Sangkala (2006), modal intelektual adalah aset berbasis pengetahuan dalam perusahaan yang menjadi basis kompetensi inti perusahaan yang dapat memengaruhi daya tahan dan keunggulan bersaing. Sementara menurut

Dalam berbagai penelitian dari berbagai disiplin ilmu, para peneliti mengidentifikasi modal intelektual atau aset tidak berwujud, sebagai semua sumber daya, properties dan attributes, atau sebagai aset non moneter yang dapat menghasilkan nilai atau manfaat masa depan (Choong, 2008). Dari sejumlah definisi diatas, dapat disimpulkan bahwa sebagai sebuah konsep, modal intelektual merujuk pada kekayaan tidak berwujud atau modal-modal non-fisik atau modal tidak kasat mata yang terkait dengan pengetahuan, teknologi, karyawan, manajemen proses dalam perusahaan yang merupakan keunggulan kompetitif perusahaan dan berguna dalam aktivitas operasional serta penciptaan nilai perusahaan. 


\section{JURNAL NOMINAL / VOLUME VIII NOMOR 2 / TAHUN 2019}

\section{Komponen Modal Intelektual}

Secara umum, para peneliti mengidentifikasi tiga konstruk utama dari modal intelektual yaitu: human capital, organizational capital, dan relational capital. Sawarjuno (2003), modal intelektual terdiri dari 3 (tiga) elemen, yaitu:

\section{Human Capital.}

Merupakan sumber inovasi dan pengembangan.

Mencerminkan

kemampuan kolektif perusahaan untuk menghasilkan solusi terbaik berdasarkan pengetahuan yang dimiliki oleh orangorang yang ada di dalam perusahaan tersebut.

2. Organizational capital.

Merupakan kemampuan organisasi atau perusahaan dalam memenuhi proses rutinitas perusahaan dan strukturnya yang mendukung usaha karyawan untuk menghasilkan kinerja intelektual yang optimal, misalnya: sistem operasional perusahaan, proses manufaktur budaya organisasi, filosofi manajemen, dan semua bentuk intellectual property, yang dimiliki perusahaan.

3. Relational capital.

Merupakan komponen modal intelektual yang memberikan nilai secara nyata. Relational capital merupakan hubungan yang harmonis yang dimiliki oleh perusahaan dengan para mitranya, baik yang berasal dari para pemasok yang andal dan berkualitas, berasal dari konsumen yang loyal dan merasa puas terhadap pelayanan perusahaan, berasal dari hubungan perusahaan dengan pemerintah, maupun dengan masyarakat sekitar.

\section{Pengungkapan Modal Intelektual}

Hendriksen (1991) mendefinisikan pengungkapan sebagai penyajian sejumlah informasi yang dibutuhkan untuk pengoperasian pasar modal yang efisien. Terdapat 2 (dua) jenis pengungkapan. Pertama pengungkapan yang bersifat wajib, yaitu pengungkapan informasi yang wajib dilakukan oleh perusahaan yang didasarkan pada peraturan atau standar tertentu. Pengungkapan yang kedua adalah yang bersifat sukarela, yaitu pengungkapan informasi yang melebihi persyaratan minimum dari peraturan yang berlaku. Pengungkapan modal intelektual merupakan pengungkapan yang terdapat dalam laporan tahunan perusahaan. Pengungkapan moda intelektual dalam laporan tahunan bersifat sukarela karena belum ada peraturan yang mewajibkan perusahaan-perusahaan publik untuk melaporkan modal intelektual dalam laporan tahunannya. Oleh karena itu perusahaan dapat memilih untuk mengungkapkan atau tidak mengungkapkannya dalam laporan tahunan perusahaan.

Perusahaan-perusahaan melakukan pengungkapan modal intelektual karena berbagai alasan. Pengungkapan modal 


\section{JURNAL NOMINAL / VOLUME VIII NOMOR 2 / TAHUN 2019}

intelektual merupakan informasi yang bernilai bagi investor, yang dapat membantu mereka mengurangi ketidakpastian mengenai prospek ke depan dan memfasilitasi ketepatan penilaian terhadap perusahaan. Selain itu juga pengungkapan modal intelektual juga berperan dalam menciptakan kepercayaan dan rasa aman bagi stakeholder. Kepercayaan penting dalam jangka panjang bagi perusahaan sebagai suatu strategi dalam menciptakan komitmen stakeholder yang lebih tinggi untuk masa depan perusahaan (Bruggen et.al., 2009). Pengungkapan modal intelektual juga dapat digunakan juga sebagai alat pemasaran, perusahaan dapat memberikan bukti tentang nilai-nilai yang diterapkan serta kemampuan perusahaan dalam menciptakan kekayaan sehingga dapat menciptakan reputasi (Fitriani, 2012). Selain itu dengan melakukan pengungkapan modal intelektual, perusahaan dapat mengatasi masalah yang ada dalam hubungan keagenan seperti asimetri informasi.

Terkait dengan relational capital, hubungan yang terjalin antara perusahaan dengan para mitranya seringkali disampaikan dalam laporan tahunan. Hal tersebut dilakukan sebagai bentuk penyampaian informasi kepada pengguna laporan bahwa kelangsungan hidup perusahaan didukung oleh berbagai pihak (stakeholder) sehingga menciptakan hubungan yang saling menguntungkan dan pada akhirnya berdampak pada peningkatan kinerja perusahaan diantaranya melalui penurunan biaya dan peningkatan pangsa pasar.

\section{Kinerja Perusahaan}

Kinerja keuangan perusahaan merupakan penentuan ukuran-ukuran tertentu yang dapat mengukur keberhasilan perusahaan dalam menghasilkan laba. Kinerja keuangan merupakan salah satu faktor yang menunjukkan efektifitas dan efisiensi suatu organisasi dalam rangka mencapai tujuannya. Perusahaan yang dapat memanfaatkan sumber daya strategisnya dengan baik diyakini mampu menciptakan suatu nilai tambah dan keunggulan kompetitif yang nantinya bermuara pada peningkatan kinerja perusahaan.

\section{Pengaruh Pengungkapan Relational}

\section{Capital pada Pendapatan}

Beberapa penelitian terdahulu menemukan hubungan antara relational capital dengan kinerja keuangan (Ashton, 2005). Beberapa penelitian telah menunjukkan hubungan relational capital dengan profitabilitas perusahaan, dan menekankan pentingnya hubungan dan network perusahaan untuk mencapai kesuksesan dan menghasilkan pertumbuhan. Hal ini memicu para peneliti untuk menguji kontribusi pengungkapan relational capital terhadap ukuran kinerja keuangan tertentu.

Dengan mengkomunikasi hubungan yang baik dengan para stakeholder-nya melalui pengungkapan, akan berdampak pada 
reputasi dan legitimasi perusahaan dalam lingkungan internal dan eksternal. Dengan demikian, pengungkapan oleh perusahaan dapat dipandang sebagai mekanisme yang dipakai oleh manajemen untuk memengaruhi persepsi pihak eksternal terhadap perusahaan. Oleh sebab itu, pengungkapan dan publikasi informasi tentang relational capital perusahaan tentunya akan dapat segera memengaruhi kinerja perusahaan. Beberapa survey yang dilakukan terkait peran relational capital, telah menganalisis bagaimana jenis modal intelektual ini, khususnya untuk dimensi yang terkait dengan konsumen dapat menciptakan nilai dalam perusahaan dan menunjukkan bagaimana terjadinya hubungan positif antara relational capital dengan kinerja perusahaan. Relasi yang kuat dengan konsumen, dapat meningkatkan legitimasi dan reputasi perusahaan dan dapat menurunkan ketidakpastian terkait transaksi dengan konsumen, sehingga selanjutnya, dekatnya hubungan tersebut dapat berpengaruh secara positif terhadap penjualan perusahaan, karena konsumen menjadi cenderung untuk melakukan pembelian lagi.

Penelitian ini menggunakan ukuranukuran kinerja berupa : tingkat pendapatan; nilai perusahaan sebagai proksi nilai pasar perusahaan; arus kas operasi bersih; dan pengeluaran modal.
Berdasarkan teori dan hasil penelitian tersebut, maka hipotesis penelitian ini adalah:

H1: Pengungkapan relational capital berpengaruh positif terhadap pendapatan

\section{Pengaruh pengungkapan relational capital pada nilai perusahaan}

Beberapa penelitian terdahulu, telah menunjukkan bahwa perusahaan dengan pengungkapan modal intelektual yang tinggi akan dipandang memiliki nilai yang tinggi oleh para stakeholder-nya (Chen, 2006). Secara khusus, beberapa penelitian telah membuktikan hubungan yang kuat antara relational capital, dan pengungkapan relational capital dengan nilai pasar perusahaan (Edvinson dan Mallone, 1997; Riahi-Belkaoui, 2003; Firer dan Mitchell Williams, 2003). Terkait dengan relational capital, dipercaya bahwa perusahaan dengan hubungan baik yang kuat dengan para stakeholder memiliki kemampuan untuk memperoleh sumber daya yang penting untuk meraih keunggulan kompetitifnya, dan selanjutnya keunggulan kompetitif yang dimiliki tersebut dapat meningkatkan nilai pangsa pasar perusahaan (Park dan Luo, 2001).

Hubungan yang kuat antara perusahaan dengan stakeholder, dapat meningkatkan reputasi dan legitimasi perusahaan, yang kemudian akan berdampak signifikan pada persepsi stakeholder eksternal tentang 
perusahaan, dan selanjutnya berdampak pada meningkatnya nilai pasar perusahaan.

Berdasarkan teori dan hasil penelitian sebelumnya, maka rumusan hipotesis penelitian ini adalah:

H2: Pengungkapan relational capital berpengaruh positif pada nilai perusahaan.

Pengaruh pengungkapan relational capital pada arus kas operasi bersih

Relational capital, secara khusus hubungan dengan pemasok dan mitra bisnis eksternal lainnya, dapat membantu perusahaan untuk memperoleh legitimasi dan meningkatkan bargaining power perusahaan untuk menekan perilaku oportunistik oleh pemasok dan mitra bisnis lainnya, sehingga dapat memperkuat posisi perusahaan terkait distribution channel, dan selanjutnya untuk mengurangi keseluruhan biaya produksi dengan dampak positif pada modal kerja perusahaan dan tingkat likuiditasnya. Srivastava et.al. (1998) menunjukkan bahwa item-item yang berbeda dari relational capital seperti hubungan dengan konsumen, channel relationship dan hubungan dengan mitra bisnis, dapat meningkatkan arus kas perusahaan dan dapat menurunkan volatilitas arus kas, dengan dampak yang positif pada nilai perusahaan.

Berdasarkan teori dan hasil penelitian sebelumnya, maka rumusan hipotesis penelitian ini adalah:
H3: Pengungkapan relational capital berpengaruh positif pada arus kas operasi bersih.

\section{METODE PENELITIAN}

\section{Jenis Penelitian}

Jenis penelitian ini dirancang sebagai penelitian kausal dengan pendekatan kuantitatif. Penelitian kausal berguna untuk mengukur hubungan antara variabel riset, atau untuk menganalisis pengaruh suatu variabel terhadap variabel lainnya. Peneliti menggunakan desain penelitian ini untuk memberikan bukti empiris dan menganalisis pengaruh variabel pengungkapan relational capital terhadap kinerja keuangan perusahaan.

\section{Populasi dan Sampel}

Populasi yang digunakan dalam penelitian ini adalah seluruh perusahaan yang terdaftar di Bursa Efek Indonesia (BEI). Penelitian ini mengambil sampel perusahaan yang go publik pada tahun 2014-2017 dengan mengambil sampel secara purposive (purposive sampling) yaitu sampel ditarik sejumlah tertentu dari populasi dengan menggunakan kriteria tertentu. Dalam hal ini sampel yang diambil harus memenuhi beberapa karakteristik berikut:

1. Perusahaan yang dijadikan sampel termasuk dalam pembagian klasifikasi menurut GICS (Global Industries Classification Standard) yang dikembangkan oleh Morgan Stanley 


\section{JURNAL NOMINAL / VOLUME VIII NOMOR 2 / TAHUN 2019}

Capital International (MSCI) dan Standard and Poors (S\&P), mengacu pada penelitian Woodcock et.al. (2009). Dari pengelompokan tersebut, tipe industri dikelompokkan menjadi dua yaitu, High-IC Intensive Industries dan Low-IC Intensive Industries. Perusahaan yang menjadi sampel adalah perusahaan yang termasuk dalam kelompok High-IC Intensive Industries, diantaranya perusahaan perbankan, telekomunikasi, elektronik, komputer dan multimedia, otomotif dan farmasi.

2. Perusahaan tersebut terdaftar di Bursa Efek Indonesia dan menerbitkan laporan keuangan per tanggal 31 Desember 20142017.

3. Perusahaan yang melaporkan laporan keuangannya dalam mata uang rupiah.

\section{Jenis dan Sumber Data}

Jenis data yang digunakan dalam penelitian ini adalah data kuantitatif, yaitu merupakan data yang berbentuk bilangan atau angka. Penelitian ini menggunakan data sekunder berupa laporan tahunan perusahaan High-IC Intensive Industries yang diperoleh dari Indonesian Stock Exchange.

\section{Variabel penelitian}

Variabel dependen yang digunakan dalam penelitian ini adalah Kinerja Keuangan Perusahaan yang terdiri dari: tingkat pendapatan; nilai perusahaan sebagai proksi nilai pasar perusahaan; dan arus kas operasi bersih (Y). Sementara variabel independen (X) dalam penelitian ini adalah Pengungkapan Relational Capital.

\section{Variabel Kinerja Keuangan}

Varibel dependen yang digunakan dalam penelitian ini adalah varibel kinerja keuangan. Kinerja keuangan perusahaan merupakan penentuan ukuran-ukuran tertentu yang dapat mengukur keberhasilan perusahaan dalam menghasilkan laba. Dalam penelitian ukuran kinerja keuangan perusahaan yang digunakan adalah tingkat pendapatan; nilai perusahaan sebagai proksi nilai pasar perusahaan; dan arus kas operasi bersih. Variabel Kinerja keuangan yagn digunakan adalah:

1. Penjualan Bersih

2. Nilai Perusahaan yang diukur dengan:

(Harga penutupan saham $\mathrm{x}$ jumlah saham biasa beredar) + nilai tercatat saham preferen + Total Hutang + kepemilikan minoritas - Kas - Investasi Jangka Pendek.

3. Arus Kas Operasi

\section{Variabel Pengungkapan Relational \\ Capital}

Variabel pengungkapan relational capital dalam penelitian ini diukur dengan menggunakan framework ICD yang dibangun berdasarkan komponen pengungkapan modal intelektual yang dikembangkan oleh Ulum, et.al (2015) yang merupakan pengembangan dari Guthrie et.al (1999). Pengungkapan modal intelektual tersebut terdiri 36 item yang 
terdiri dari: 8 item kategori human capital, 15 item structural capital, dan 13 item relational capital. Fokus penelitian ini adalah pada item-item pengungkapan modal intelektual yang termasuk kategori relational capital yang terdiri dari 13 item pengungkapan. Analisis data untuk tingkat pengungkapan variabel relational capital dilakukan dengan cara sistem kode numerik yang dikembangkan oleh Guthrie et.al (1999), yaitu:

0 apabila item tidak diungkapkan

1 apabila item diungkapkan dalam bentuk narasi

2 apabila item diungkapkan dalam bentuk numerik

3 apabila item diungkapkan dengan nilai moneter.

Item-item pengungkapan relational capital tersebut adalah:

- Brand

$0-1$

- Pelanggan

- Loyalitas Pelanggan

- Nama Perusahaan $0-1$

- Jaringan Distribusi

- Kolaborasi bisnis

- Perjanjian Lisensi

- Kontrak-kontrak yang menguntungkan

- Perjanjian franchise

- Penghargaan $0-2$

- Sertifikasi

- Strategi Pemasaran

$0-1$
- Pangsa Pasar

Pengukuran indeks pengungkapan relational capital menggunakan rumus: Indeks pengungkapan relational capital $=$ Jumlah pengungkapan yang dilakukan perusahaan

Jumlah pengungkapan yang seharusnya dilakukan.

\section{Metode Analisis Data}

Pengujian hipotesis dalam penelitian ini adalah menggunakan model analisis regresi berganda dengan alat uji pengolahan data yaitu software SPSS. Penelitian ini akan menguji pengaruh pengungkapan relational capital terhadap kinerja keuangan perusahaan. Persamaan regresi yang digunakan adalah sebagai berikut:

$$
\begin{aligned}
& \text { Rev }=\alpha+\beta 1 \mathrm{RC}+\beta 2 \mathrm{TA}+e \\
& \text { E_Value }=\alpha+\beta 1 \mathrm{RC}+\beta 2 \mathrm{TA}+e \\
& \text { NOCF }=\alpha+\beta 1 \mathrm{RC}+\beta 2 \mathrm{TA}+e
\end{aligned}
$$

Keterangan:

$$
\alpha \text { : Konstanta }
$$

$\beta$ : Koefisien Regresi

Rev : Pendapatan tahunan

E_Value : Nilai Perusahaan

$N O C F$ : Arus Kas Operasi Bersih

$R C$ : Relational Capital

$T A$ : Total Aset

$e \quad$ : Error

\section{HASIL PENELITIAN DAN \\ PEMBAHASAN}




\section{JURNAL NOMINAL / VOLUME VIII NOMOR 2 / TAHUN 2019}

Berdasarkan metoda purposive sampling maka diperoleh sebanyak total 72 observasi perusahaan tahun (firm-year observation) yang memenuhi syarat sebagai sampel penelitian. Dalam penelitian ini, variabel relational capital diuji pengaruhnya terhadap 3 (tiga) variabel kinerja keuangan, yaitu: penjualan bersih, arus kas operasi, nilai perusahaan. Untuk itu, berikut ini adalah tabel yang menjelaskan hasil seleksi sampel penelitian untuk pengujian terhadap masingmasing variabel kinerja keuangan.

Tabel 1 : Sampel Penelitian

\begin{tabular}{|c|c|c|}
\hline No & Keterangan & $\begin{array}{c}\text { Jumlah } \\
\text { Observasi }\end{array}$ \\
\hline 1 & $\begin{array}{l}\text { Sampel penelitian } \\
\text { untuk pengujian } \\
\text { pengaruh } \\
\text { relational capital } \\
\text { pada penjualan } \\
\text { bersih }\end{array}$ & 72 \\
\hline 2 & $\begin{array}{l}\text { Sampel penelitian } \\
\text { untuk pengujian } \\
\text { pengaruh } \\
\text { relational capital } \\
\text { pada nilai } \\
\text { perusahaan }\end{array}$ & 70 \\
\hline 3 & $\begin{array}{l}\text { Sampel penelitian } \\
\text { untuk pengujian } \\
\text { pengaruh } \\
\text { relational capital } \\
\text { pada arus kas } \\
\text { operasi }\end{array}$ & 54 \\
\hline
\end{tabular}

\section{Statistik Deskriptif}

Didasarkan pada metoda purposive sampling, untuk memperoleh sampel penelitian maka diperoleh total 72 observasi yang bisa dijadikan sampel penelitian untuk pengujian pengaruh terhadap pendapatan bersih, 70 observasi yang bisa dijadikan sampel penelitian untuk pengujian pengaruh terhadap nilai perusahaan, dan 54 observasi yang bisa dijadikan sampel penelitian untuk pengujian pengaruh terhadap variabel arus kas operasi..

Selengkapnya mengenai statistic deskriptif data penelitian dapat dilihat pada tabel berikut:

Tabel 2 : Hasil Uji Descriptive Statistics

\begin{tabular}{lcccrr}
\hline & N $\begin{array}{c}\text { Minim } \\
\text { um }\end{array}$ & $\begin{array}{l}\text { Maxi } \\
\text { mum }\end{array}$ & $\begin{array}{r}\text { Mean } \\
\text { Deviati } \\
\text { on }\end{array}$ \\
\hline Rev & 72 & 10.94 & 14.31 & 12.331 & .74765 \\
& & & 1 & \\
E_Value & 70 & 11.10 & 15.20 & 13.151 & 1.0406 \\
& & & 6 & 8 \\
NOCF & 54 & 9.54 & 13.69 & 11.744 & .91071 \\
& & & & 1 & \\
TA & 72 & 26.00 & 33.00 & 29.378 & 1.8483 \\
& & & & 4 & 8 \\
RC & 72 & .23 & .82 & .5005 & .13507 \\
\hline
\end{tabular}

Pengungkapan Modal Relasi (Relational

\section{Capital Disclosure)}

Dari data pada tabel statistik deskriptif diatas, rata-rata pengungkapan modal relasi (relational capital) perusahaan sampel pada perioda tahun 2014-2017 adalah sebesar $50 \%$ dari total item pengungkapan modal relasi dengan standar deviasi 13,5\%. Jumlah pengungkapan modal relasi terendah adalah sebesar $23 \%$ dan jumlah pengungkapan modal relasi tertinggi adalah sebesar $82 \%$.

\section{Pengujian Asumsi Klasik}

\section{Uji Normalitas}




\section{JURNAL NOMINAL / VOLUME VIII NOMOR 2 / TAHUN 2019}

Pengujian normalitas dengan uji statistik non-parametrik Kolmogorov Smirnov. Dasar pengambilan keputusan untuk analisis statistik adalah jika nilai probabilitas signifikansi $\geq 0,05$ maka data dikatakan berdistribusi secara normal.

Dalam penelitian ini, dilakukan 3 (tiga) kali regresi berganda untuk menguji 3 (tiga) hipotesis penelitian tentang pengaruh pengungkapan modal relasi (relational capital) terhadap 3 (tiga) variabel dependen kinerja keuangan perusahaan yaitu, pendapatan bersih, nilai perusahaan, dan arus kas operasi bersih. Untuk itu terdapat juga 3 (tiga) kali pengujian normalitas residual data penelitian yang masing-masing ditampilkan berikut ini:

Tabel 3 : One-Sample KolmogorovSmirnov Test

\begin{tabular}{llcr}
\hline & \multicolumn{1}{c}{ Variable } & $\begin{array}{c}\text { Kolmo } \\
\text { gorov- } \\
\text { Smirno } \\
\text { v Z }\end{array}$ & $\begin{array}{c}\text { Asym } \\
\text { p. Sig. } \\
(2- \\
\text { tailed })\end{array}$ \\
\hline $\mathrm{H} 1$ & $\begin{array}{l}\text { Pengungkapan } \\
\text { relational } \\
\text { capital }-> \\
\text { pendapatan }\end{array}$ & .705 & .702 \\
$\mathrm{H} 2$ & & \\
& $\begin{array}{l}\text { Pengungkapan } \\
\text { relational } \\
\text { capital }->\text { nilai } \\
\text { perusahaan } \\
\text { Pengungkapan } \\
\text { relational } \\
\text { capital }->\text { arus } \\
\text { kas operasi } \\
\text { bersih }\end{array}$ & .696 & .718 \\
\hline
\end{tabular}

Berdasarkan tabel diatas maka dapat disimpulkan bahwa nilai residual terdistribusi normal. Ini ditandai dengan besarnya nilai Kolmogorov-Smirnov masing-masing sebesar 0.705, 0.696, dan 0.663 pada tingkat signifikansi masingmasing sebesar $0.702,0.718$, dan 0.772 yang menunjukkan lebih besar dari tingkat signifikansi 0,05 .

\section{Uji Multikolinearitas}

Ada atau tidaknya multikolonieritas dapat dilihat dari nilai tolerance dan lawannya variance inflation factor (VIF). Variabel independen dikatakan bebas dari penyimpangan asumsi klasik multikolinearitas (tidak terdapat hubungan linier antar variabel independen) jika nilai variance inflation factor (VIF) kurang atau sama dengan angka 5 (VIF $\leq 5)$. Dan batas toleransi setiap variabel independen tidak boleh kurang dari 0.1 (Toleransi $>0.1$ ). Berikut adalah hasil dari 3 (tiga) pengujian multikolonearitas untuk 3 (tiga) hipotesis dalam penelitian ini.

Tabel 4 : Uji Multikolinearitas

\begin{tabular}{|c|c|c|c|}
\hline Variable & & $\begin{array}{c}\text { Tole } \\
\text { ranc } \\
\mathrm{e}\end{array}$ & VIF \\
\hline \multirow{2}{*}{$\begin{array}{l}\text { Pengungkapan } \\
\text { relational capital - } \\
>\text { pendapatan }\end{array}$} & TA & .991 & 1.010 \\
\hline & $\mathrm{RC}$ & .991 & 1.010 \\
\hline Pengungkapan & TA & 991 & 1.009 \\
\hline $\begin{array}{l}\text { relational capital - } \\
>\text { nilai perusahaan }\end{array}$ & $\mathrm{RC}$ & .991 & 1.009 \\
\hline Pengungkapan & TA & .975 & 1.025 \\
\hline $\begin{array}{l}\text { relational capital - } \\
>\text { arus kas operasi } \\
\text { bersih }\end{array}$ & $\mathrm{RC}$ & .975 & 1.025 \\
\hline
\end{tabular}




\section{JURNAL NOMINAL / VOLUME VIII NOMOR 2 / TAHUN 2019}

Dari hasil uji multikolinearitas menunjukkan bahwa setiap variabel independent yang digunakan dalam penelitian ini tidak terdapat penyimpangan klasik multikolinearitas yang berarti tidak terdapat hubungan linier antar variabel independen karena memiliki nilai Tolerance yang lebih besar dari batas toleransi yaitu 0.10 dan cenderung mendekati angka 1 , serta nilai VIF yang lebih kecil dari batas VIF yaitu 5.00.

\section{Uji Heterokedastisitas}

Model regresi yang baik adalah yang bebas dari heterokedastisitas. Untuk mendeteksi ada tidaknya heterokedastisitas dapat dilakukan dengan melihat ada tidaknya pola tertentu pada grafik plot antara ZPRED (dependen) dan SRESID (residual). Jika terjadi pola tertentu, maka mengindikasikan telah terjadi heterokedastisitas. Dan sebaliknya jika tidak ada pola yang jelas serta titik-titiknya menyebar, maka tidak terjadi heterokedastisitas.

Dapat disimpulkan bahwa data yang digunakan dalam penelitian ini tidak terdapat unsur heterokedastisitas. Hal ini terlihat pada butiran-butiran data yang tersebar acak diatas dan dibawah angka nol pada sumbu $\mathrm{Y}$, dan tidak menggumpal.

\section{Analisis Data}

\section{Uji Koefisien Determinasi $\left(\mathbf{R}^{\mathbf{2}}\right)$}

Uji Koefisien Determinasi bertujuan untuk mengetahui seberapa besar kemampuan model menjelaskan variasi di dalam variabel dependen (Ghozali, 2006). Nilai $R^{2}$ berkisar antara 0 sampai $1\left(0 \leq R^{2} \leq\right.$ 1), semakin nilai $\mathrm{R}^{2}$ mendekati angka 1 , semakin besar pengaruh variabel independen terhadap variabel dependen yang berarti variabel-variabel independen yang dipakai dalam penelitian memberikan hampir semua informasi yang dibutuhkan untuk memprediksi variasi variabel dependen. Berikut adalah 3 (tiga) hasil pengujian koefisien determinasi $\left(\mathrm{R}^{2}\right)$ dari 3 (tiga) pengujian hipotesis dalam penelitian ini:

Tabel 5 : Hasil Uji Koefisien Determinasi

\begin{tabular}{|c|c|c|c|}
\hline & Variable & $\begin{array}{l}\text { Adjusted } \\
\text { R Square }\end{array}$ & $\begin{array}{l}\text { Std. } \\
\text { Error of } \\
\text { the } \\
\text { Estimat } \\
\text { e }\end{array}$ \\
\hline H1 & $\begin{array}{l}\text { Pengungkapa } \\
\mathrm{n} \text { relational } \\
\text { capital -> } \\
\text { pendapatan }\end{array}$ & .336 & .60936 \\
\hline $\mathrm{H} 2$ & $\begin{array}{l}\text { Pengungkapa } \\
\mathrm{n} \text { relational } \\
\text { capital -> } \\
\text { nilai } \\
\text { perusahaan }\end{array}$ & .423 & .79047 \\
\hline H3 & $\begin{array}{l}\text { Pengungkapa } \\
\mathrm{n} \text { relational } \\
\text { capital -> } \\
\text { arus kas } \\
\text { operasi bersih }\end{array}$ & .327 & .74739 \\
\hline
\end{tabular}

Berdasarkan pada tabel-tabel diatas terlihat bahwa kolom Adjusted $R$ Square 


\section{JURNAL NOMINAL / VOLUME VIII NOMOR 2 / TAHUN 2019}

untuk pengujian hipotesis pertama menunjukan nilai 0.336 atau sebesar 33.6\%, yang memiliki arti bahwa kemampuan variabel modal relasi (relational capital) dalam menyediakan informasi penting untuk menjelaskan variabel pendapatan bersih adalah sebesar $33.6 \%$. Pada tabel berikut, untuk pengujian hipotesis kedua kolom Adjusted R Square menunjukan nilai 0.423 atau sebesar 42.3\%, yang memiliki arti bahwa kemampuan variabel modal relasi (relational capital) dalam menyediakan informasi penting untuk menjelaskan variabel nilai perusahaan adalah sebesar 42.3\%. Pada tabel selanjutnya, untuk pengujian hipotesis ketiga kolom Adjusted $R$ Square menunjukan nilai 0.327 atau sebesar $32.7 \%$, yang memiliki arti bahwa kemampuan variabel modal relasi (relational capital) dalam menyediakan informasi penting untuk menjelaskan variabel arus kas operasi adalah sebesar $32.7 \%$.

\section{Uji Statistik t}

Berikut adalah tabel hasil uji statistik t pengaruh variabel modal relasi (relational capital) terhadap masing-masing variabel dependen, yaitu :pendapatan bersih, nilai perusahaan, dan arus kas operasi:

Tabel 6 : Hasil Uji t

\begin{tabular}{llccl}
\hline & & $\begin{array}{c}\text { Var } \\
\text { iabl } \\
\text { e }\end{array}$ & $\begin{array}{c}\text { P } \\
\text { Valu } \\
\text { es }\end{array}$ & Conclusion \\
\hline H1 & $\begin{array}{l}\text { Pengun } \\
\text { gkapan } \\
\text { relation } \\
\text { al }\end{array}$ & TA & .337 & \\
& RC & .000 & Supported \\
& & & \\
& & & & \\
& & &
\end{tabular}

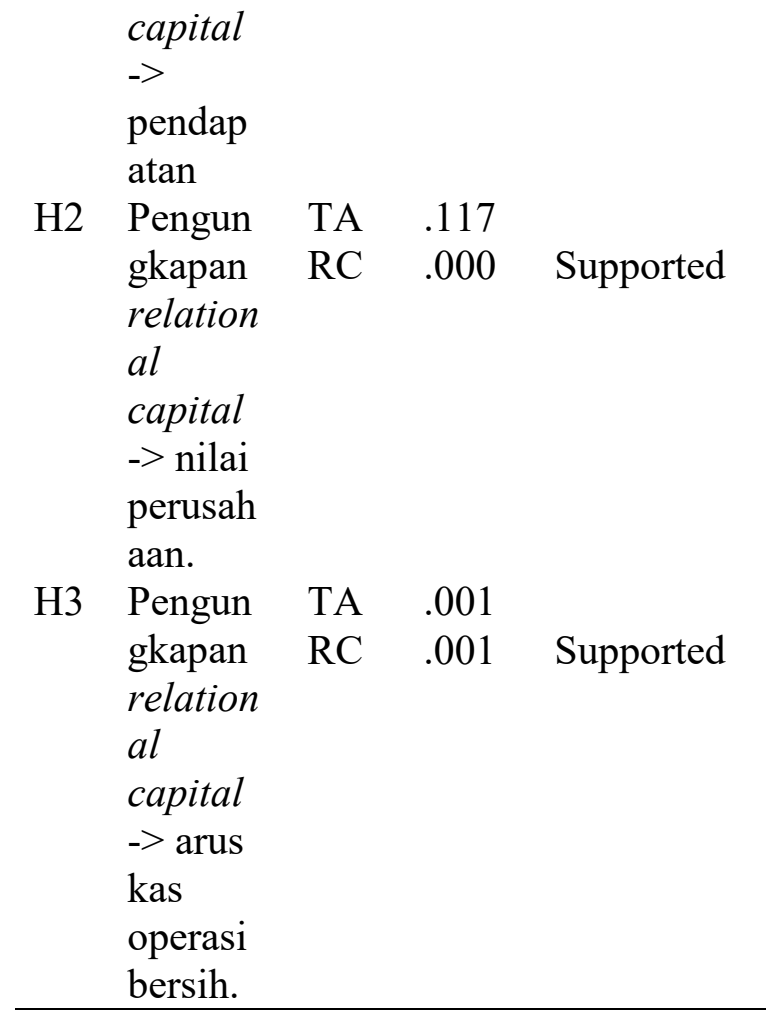

Dari hasil uji statistik t di atas, terlihat bahwa variabel independen pengungkapan modal relasi (relational capital) yang dalam penelitian ini diuji pengaruhnya terhadap 3 (tiga) variabel dependen kinerja keuangan perusahaan, yaitu pendapatan bersih, nilai perusahaan, dan arus kas operasi secara empiris semuanya terbukti berpengaruh signifikan. Hal ini terlihat dari besaran nilai signifikansi variabel pengungkapan modal relasi (relational capital), pada semua hipotesis yang menghasilkan nilai signifikansi dibawah 0.05. Dengan melihat unstandardized coefficient dapat dirumuskan persamaan-persamaan berikut:

Rev $=9.617+3.204 \mathrm{RC}+0.038 \mathrm{TA}+e$

E_Value $=8.368+4.816 \mathrm{RC}+0.081 \mathrm{TA}+e$ $N O C F=4.852+2.619 \mathrm{RC}+0.190 \mathrm{TA}+e$ Keterangan: 


\author{
$\alpha \quad$ : Konstanta \\ $\beta$ : Koefisien Regresi \\ Rev : Pendapatan tahunan \\ E_Value : Nilai Perusahaan \\ $N O C F$ : Arus Kas Operasi Bersih \\ $R C$ : Relational Capital \\ $T A$ : Total Aset \\ $e \quad$ : Error
}

\section{Pembahasan}

\section{Pengaruh Pengungkapan Relational}

\section{Capital terhadap Pendapatan}

Hasil pengujian hipotesis 1 (satu) penelitian ini memberikan bukti empiris bahwa pengungkapan relational capital berpengaruh terhadap pendapatan bersih perusahaan. Relasi yang kuat dengan konsumen, dapat meningkatkan legitimasi dan reputasi perusahaan dan dapat menurunkan ketidakpastian terkait transaksi dengan konsumen, sehingga selanjutnya, dekatnya hubungan tersebut dapat berpengaruh secara positif terhadap pendapatan penjualan perusahaan, karena konsumen menjadi cenderung untuk melakukan pembelian lagi. Pengungkapan informasi yang berkaitan dengan kepercayaan konsumen, kepuasan konsumen, loyalitas konsumen, image dan reputasi perusahaan, kolaborasi bisnis dan perjanjianperjanjian lisensi, dapat meningkatkan kinerja keuangan perusahaan.
Bukti empiris penelitian ini sejalan dengan beberapa penelitian, diantaranya penelitian Ashton (2005) yang menemukan hubungan antara relational capital dengan kinerja keuangan. Beberapa penelitian lain pun menemukan hubungan antara relational capital dengan profitabilitas diantaranya Davey et.al (2009) dan Hormiga et.al (2011). Penelitian ini pun sejalan dengan penelitian Martini et.al (2016) yang menemukan bukti empiris pengaruh pengungkapan relational capital pada pendapatan bersih perusahaanperusahaan di Eropa.

\section{Pengaruh Pengungkapan Relational}

\section{Capital terhadap Nilai Perusahaan}

Hasil pengujian hipotesis 2 (dua) penelitian ini memberikan bukti empiris bahwa pengungkapan relational capital berpengaruh terhadap nilai perusahaan. Hubungan yang kuat antara perusahaan dengan stakeholder, dapat meningkatkan reputasi dan legitimasi perusahaan, yang kemudian akan berdampak signifikan pada persepsi stakeholder eksternal tentang perusahaan, dan selanjutnya berdampak pada meningkatnya nilai pasar perusahaan. Terkait dengan relational capital, dipercaya bahwa perusahaan dengan hubungan baik yang kuat dengan para stakeholder memiliki kemampuan untuk memperoleh sumber 


\section{JURNAL NOMINAL / VOLUME VIII NOMOR 2 / TAHUN 2019}

daya yang penting untuk meraih keunggulan kompetitifnya, dan selanjutnya keunggulan kompetitif yang dimiliki tersebut dapat meningkatkan nilai pangsa pasar perusahaan (Park dan Luo, 2001).

Bukti empiris penelitian ini sejalan dengan beberapa penelitian, diantaranya penelitian Chen (2006) yang menunjukkan bahwa perusahaan dengan tingkat pengungkapan modal intelektual yang tinggi dipandang memiliki nilai perusahaan yang tinggi oleh stakeholder eksternal. Secara khusus, beberapa penelitian telah membuktikan hubungan yang kuat antara relational capital, dan pengungkapan relational capital dengan nilai pasar perusahaan (Edvinson dan Mallone, 1997; Riahi-Belkaoui, 2003; Firer dan Mitchell Williams, 2003).

\section{Pengaruh Pengungkapan Relational}

\section{Capital terhadap Arus Kas Operasi}

Hasil pengujian hipotesis 3 (tiga) penelitian ini memberikan bukti empiris bahwa pengungkapan relational capital berpengaruh terhadap arus kas operasi perusahaan. Relational capital, secara khusus hubungan dengan pemasok dan mitra bisnis eksternal lainnya, dapat membantu perusahaan untuk memperoleh legitimasi dan meningkatkan bargaining power perusahaan untuk menekan perilaku oportunistik oleh pemasok dan mitra bisnis lainnya, sehingga dapat memperkuat posisi perusahaan terkait distribution channel, dan selanjutnya untuk mengurangi keseluruhan biaya produksi dengan dampak positif pada modal kerja perusahaan dan tingkat likuiditasnya. Srivastava et.al. (1998) menunjukkan bahwa item-item yang berbeda dari relational capital seperti hubungan dengan konsumen, channel relationship dan hubungan dengan mitra bisnis, dapat meningkatkan arus kas perusahaan dan dapat menurunkan volatilitas arus kas, dengan dampak yang positif pada nilai perusahaan. Penelitian ini pun sejalan dengan penelitian Martini et.al (2016) yang menemukan bukti empiris pengaruh pengungkapan relational capital pada arus kas operasi bersih perusahaan-perusahaan di Eropa.

\section{SIMPULAN DAN SARAN}

Berdasarkan hasil analisis data dan pembahasan yang telah dilakukan, maka dapat diambil kesimpulan sebagai berikut:

1. Pengungkapan Relational Capital berpengaruh pada pendapatan bersih perusahaan

2. Pengungkapan Relational Capital berpengaruh pada nilai perusahaan.

3. Pengungkapan Relational Capital berpengaruh pada arus kas operasi perusahaan 
Keterbatasan penelitian ini terutama terkait penggunaan variabel kinerja yang hanya terbatas pada 3 (tiga) ukuran kinerja keuangan saja dan sampel penelitian yang hanya menggunakan perusahaan yang termasuk dalam kelompok High IC-Intensive Industries.

Saran untuk penelitian selanjutnya yang didasarkan pada keterbatasan penelitian ini adalah penggunaan ukuran kinerja yang lain dan menguji pengaruh relational capital pada jenis perusahaan lainnya.

\section{DAFTAR PUSTAKA}

Adecoo. (2007). The Intrinsic Link Between Human and Relational Capital : a key differentiator for today's leading knowledge economy companies.

Ashton, R. H.. (2005). Intellectual Capital and Value Creation: A Review. Journal of Accounting Literature Vol. 24, No. 1, pp.53-134.

Beattie, V., and Thompson S.J. (2007). Lifting the Lid on the Use of Content Analysis to Investigate Intellectual Capital Disclosure..Accounting Forum Vol.31 No. 2 pp. 129-163.

Bontis, N. (1998). Intellectual Capital Disclosure in Canadian Corporations. Journal of Human Resource Costing and Accounting, Vol. 7 Nos. 1-2, pp. 9-20.

Bruggen, A. (2009). Intellectual capital disclosure: evidence from Australia. Managemen Decision Journal, Vol. 47 No.2, pp. 233-245.

Bukh, P. N. (2003). Commentary: The Relevance of Intellectual Capital
Disclosure: A Paradox?. Accounting, Auditing, and Accountability Journal. Vol. 16 No.1, pp. 49-56.

Chen, M., Cheng S., and Hwang, Y. (2005). An Empirical investigation of the relationship between Intellectual Capital and Firm's Market Value and Financial Performance. Journal of Intellectual Capital, Vol. 6, No.2, pp. 159-176.

Choong, K.K. (2008). Intellectual Capital: Definitions, categorization, and reporting models. Journal of Intellectual Capital, Vol.9, No.4, pp. 609-638.

Guthrie, J., and Petty R. (2000). Intellectual Capital: Australian annual reporting practices. Journal of Intellectual Capital, Vol.1, No.3, pp. 241-251.

Luo, X., Griffith D. A., Liu S. S., and Shie Y. (2004). The effects of customers relationships and social capital on firms performance: a Chinese business illustration. Journal of International Marketing, Vol. 12, No.4, pp. 25-45.

Martini, S.B., Corvino A., Doni F., and Rigolini A.. (2016). Relational capital disclosure, corporate reporting, and company performance Evidence from Europe. Journal of Intellectual Capital, Vol. 17, No.2, pp. 186-217.

Park, S. H., and Luo Y. (2001). Guanxi and organizational dynamics: organizational networking in chinese firms. Strategic Management Journal, Vol. 22, No.5, pp. 455-477.

Salehi, M., Enayati G., and Javadi P. (2014). The relationship between intellectual capital with economic value added and financial performance. Iranian Journal of Management Studies, Vol. 7, No.2, pp. 259-283. 
Sawarjuwono, T. dan Agustine P. K. (2003). Intellectual Capital: Perlakuan, Pengukuran, dan Pelaporan (Sebuah Library Research). Jurnal Akuntansi dan Keuangan, Vol. 5, No.1, pp. 3557.

Srivastava, R. K., Shervani T. A. and Fahey L. (1998). Market-based assets and shareholder value: a framework for analysis. Journal of Marketing, Vol. 7, No.2, pp. 259-283.

Tan, H. P., Plowman D., and Hancock P. (2007). Intellectual Capital and financial returns of companies. Journal of Intellectual Capital, Vol. 8, No.1, pp. 76-95. 